Brit. J. vener. Dis. (1959), 35, 27.

\title{
PPLO OF HUMAN GENITAL ORIGIN SEROLOGICAL CLASSIFICATION OF STRAINS AND ANTIBODY DISTRIBUTION IN MAN*†
}

\author{
BY \\ DOROTHY H. CARD \\ Lister Institute of Preventive Medicine, London
}

Pleuropneumonia-like organisms (PPLO) have frequently been isolated from the human genital tract since the first report by Dienes and Edsall (1937); their presence in the urethral discharge of patients with non-gonococcal urethritis (N.G.U.) aroused interest because of the unknown aetiology of the disease. The significance of PPLO in the genital tract and their association with N.G.U. are disputed. The subject has been critically reviewed by Harkness (1950), Edward (1954), and more recently by Klieneberger-Nobel (1959), who also described cultural studies made concurrently with the work reported here.

Beveridge, Campbell, and Lind (1946) detected complement-fixing antibodies to human genital PPLO in human sera, but found no association between their presence and concurrent urethritis. Harkness and Henderson-Begg (1948) could not detect antibodies in any of 25 N.G.U. patients and 25 controls, even though PPLO were isolated from fifteen of the first group. PPLO isolated from the blood of a woman with puerperal fever, from an empyema wound, and from the genital system of two other women were considered by Stokes (1955) to be the cause of clinical infection in those patients; PPLO antibody appeared in the sera, increased during the course of the infection, and had decreased 6 months later. Melén and Gotthardson (1955) made similar observations in five cases of salpingo-oophoritis. Pathogenic members of the pleuropneumonia group of organisms also induce antibody formation in animals of various species. Antibodies appear in contagious pleuropneumonia of cattle and in contagious agalactia of sheep; and may be detected by complement-fixation tests as an aid to the diagnosis of those diseases (Campbell and Turner, 1936; Zavagli, 1951).

Serological tests with an appropriate PPLO antigen offer an obvious way to determine the significance of PPLO in human urethritis. The antigen, however, must be representative of the infecting strains. Accordingly, a survey was made of 56 of the 98 strains isolated by Dr. Klieneberger-Nobel from

* This work was carried out by the author under the aegis of the * This work was carried out by the author under the aegis of the
Medical Research Council Working Party on Non-Specific Urethritis Medical Research Council Working Party on Non-Specific
with the aid of a grant from the U.S. Public Health Service.

$t$ Received for publication June 26, 1958. cases of N.G.U. and other genital infections in man. They fortunately proved to be serologically uniform; and an antigen made from one strain was therefore suitable for the exploration of PPLO antibodies in the human subject.

The instability of suspensions of human PPLO precluded the routine use of agglutination as a means of detecting antibody. The complement-fixation method, which has proved satisfactory in other serological explorations of PPLO infections (Campbell and Turner, 1936; Stokes, 1955; HuijsmansEvers and Ruys, 1956), was selected as the method of choice.

\section{Materials}

(a) Normal Saline. -0.85 per cent. $\mathrm{NaCl}$ in distilled water.

(b) Ca-Mg Saline.-Normal saline augmented with $1.8 \times 10^{-4} \mathrm{M} \mathrm{CaCl}_{2}, 0.9 \times 10^{-4} \mathrm{M} \mathrm{Mg} \mathrm{Cl}_{2}$ (Mayer, Osler, Bier, and Heidelberger, 1946), $1.95 \times 10^{-3} \mathrm{M}$ Boric acid, and $1.36 \times 10^{-4} \mathrm{M}$ sodium borate. This solution was used for diluting reagents and rinsing pipettes.

(c) Preserved Guinea-Pig Complement $\left(\mathrm{C}^{\prime}\right)$.-This was supplied by the V.D. Reference Laboratory, Whitechapel Clinic.

(d) Sheep Cells preserved in Alsever's Fluid.-These were washed three times in normal saline, resuspended in saline, and adjusted to 2.5 per cent. concentration by the haematocrit method of Price and Wilkinson (1947).

(e) "Haemolytic Immune Body".-This was supplied by the V.D. Reference Laboratory. It was diluted to a concentration of 5MHD on the basis of the titre stated on the bottle.

( $f$ ) Sensitized Red Cells.-These were prepared by mixing equal volumes of $(d)$ and $(e) 20 \mathrm{~min}$. before use.

(g) Human Sera from Various Sources.-These were inactivated, undiluted, at $56^{\circ} \mathrm{C}$. for 30 min.

\section{Methods}

(a) Preparation of Antigens.-The growth of human PPLO in liquid media is greatly improved (Edward, 1954) in the presence of the surface of a solid agar medium. Accordingly an agar base, made from $15 \mathrm{ml}$. ox-heart infusion agar and $5 \mathrm{ml}$. human serum, was allowed to set in the bottom of a 500-ml. conical flask; $400 \mathrm{ml}$. liquid medium (Klieneberger-Nobel, 1958) were 
added, and inoculated with $1 \mathrm{ml}$. overnight broth culture of the relevant PPLO strain. After incubation with shaking for 6 days at $37^{\circ} \mathrm{C}$. the culture was centrifuged at $8,500 \mathrm{G}$ for $30 \mathrm{~min}$. The deposit was suspended in about $80 \mathrm{ml}$. normal saline and centrifuged again in two equal portions. The deposit from one portion, resuspended in 10 to $12 \mathrm{ml}$. normal saline as "fresh" material, was called the $F$ antigen. The other deposit was suspended in $10 \mathrm{ml}$. distilled water, boiled for $10 \mathrm{~min}$. in a brine bath at $108^{\circ}$ and cooled, and $\mathrm{NaCl}$ was then added to give a concentration of 0.85 per cent.

This preparation of "boiled" material was called the $B$ antigen; it was not allowed to age as Campbell and Turner (1953) suggested for bovine PPLO antigen, because ageing of the human PPLO antigen did not increase its complement-fixing reactivity. Poorly dispersed suspensions were homogenized in a tissue grinder (Griffith's tube) and were stored in $10^{-4}$ merthiolate at $4^{\circ} \mathrm{C}$.

The B antigen was tested because of the observation of Campbell and Turner (1953) that a boiled preparation was more potent than a fresh preparation in the diagnostic test for contagious pleuropneumonia in cattle; though with human PPLO, the $B$ antigen proved to be the less sensitive. Nevertheless, both suspensions were used as a routine, because (see below) a given human serum might react with one or the other, or with both.

(b) Standardization of Antigen.-Antigens for the serological examination of PPLO strains were standardized by opacity. The Hilger Biochemical Absorptiometer was used with a filter of peak transmission at $610 \mathrm{~m} \mu$ and standard 16-mm. tubes. An optical density of 0.2 (log scale) was chosen, because experience showed that the optimal reacting dilution of several batches of antigen had this opacity. Within certain dilution limits the end titre of a serum was independent of the antigen dilution. Antigens for testing human sera were made from a single PPLO strain (strain 56, isolated from the human cervix). It was fully representative of the human PPLO antigens, since it cross-reacted with rabbit antisera to five other human genital PPLO at the same titre as the homologous strain (Table I). For the complementfixation test the antigen dilution giving the highest titre with rabbit antiserum to strain 56 was used; it had proved to be optimal for positive human serum. Each batch of antigen was checked before use with known negative and positive human sera.

(c) Preparation of Antisera.-PPLO cultures were grown as described above, except that rabbit serum replaced human serum in the medium. The washed organisms were suspended in normal saline at an optical density of $0 \cdot 2$, and rabbits were given the following doses intravenously at 2-day intervals: $1 \mathrm{ml}$.; $1 \mathrm{ml}$.; $2 \mathrm{ml}$.; $2 \mathrm{ml}$.; $4 \mathrm{ml}$.; $6 \mathrm{ml}$. The rabbits were bled 10 days after the final injection; and the antisera were inactivated at $56^{\circ} \mathrm{C}$. for $30 \mathrm{~min}$. at the lowest dilution tested.

(d) Complement-Titration Tests.-These were carried out in $3 \times \frac{3}{8}$ " tubes, using $0.2 \mathrm{ml}$. as the unit volume. For the complement titrations the $\mathrm{C}^{\prime}$ dilutions used were
$1 / 40,1 / 50 \ldots 1 / 120,1 / 140,1 / 160$, and $1 / 200$. Unit volumes of every $C^{\prime}$ dilution were mixed both with equal volumes of antigen dilution and $\mathrm{CaMg}$ saline, and with two volumes of the saline only; the tubes were held at $4^{\circ}$ for $18 \mathrm{hrs}$ and then at room temperature for $1 \mathrm{hr}$. Two volumes of sensitized red cells were then added and mixed with an automatic pipette, the incubation was continued at $37^{\circ} \mathrm{C}$. for $30 \mathrm{~min}$., and the tubes were finally centrifuged to deposit unhaemolysed red cells. The dilution of $\mathbf{C}^{\prime}$ which in the presence of antigen lysed 50 per cent. of the red cells was estimated by visual comparison between the incompletely lysed samples and any completely lysed sample diluted with $1 \mathrm{ml}$. saline. Twice this concentration of $\mathrm{C}^{\prime}$ was used in the complement-fixation tests.

(e) Complement-Fixation Tests.-These were similarly carried out with dilute sera substituted for saline. All sera were tested in doubling dilutions, the initial range for human sera being from $1 / 10$ to $1 / 40$, and higher dilutions tested when necessary. The serum dilution giving 50 per cent. fixation was taken as the end titre of the serum. Titres are expressed as the reciprocal of the initial serum dilution added to the complement-fixation mixtures. The lowest serum dilution was tested for anticomplementary effect. Negative sera and positive sera of known titre were included in each batch of human sera tested. A control $\mathbf{C}^{\prime}$ titration using $\frac{1}{4}, \frac{1}{2}$, and the full $C^{\prime}$ dose was made for each antigen. When the $C^{\prime}$ dose was correct these amounts produced no lysis, 50 per cent. lysis, and complete lysis respectively.

A "blank" antigen was made from $500 \mathrm{ml}$. uninoculated medium by the method described for the $\mathrm{F}$ antigen; it had a faint turbidity. When this preparation was used in the complement-fixation test with human sera diluted $1 / 10$, no complement fixation occurred with either negative or positive sera.

The conditions of complement fixation were varied to test the sensitivity of the reaction. 47 human sera chosen at random were tested by allowing complement fixation to occur both at $37^{\circ} \mathrm{C}$. for $1 \mathrm{hr}$ and at $4^{\circ} \mathrm{C}$. for 18 hrs, starting at a serum dilution of $1 / 5$ instead of $1 / 10$. Of these only 19 per cent. had a titre of at least 10 (the criterion of positivity in the routine $18-\mathrm{hr}$ test) by the 1-hr test compared with 46 per cent. by the 18 -hr test. But when titres of 5 were adopted as positive in the 1-hr test then 38 per cent. of the sera were positive. No serum was positive by the $1-\mathrm{hr}$ test and negative by the $18-\mathrm{hr}$ test. For both antigens the 18-hr titre for any serum was about four times as high as the 1-hr titre. It is therefore improbable that the two tests were detecting different antigen-antibody reactions.

\section{Results}

Serological Examination of PPLO Strains. - Antisera were made against one strain of contagious pleuropneumonia of cattle (PP cattle); and against nine PPLO strains, of which six were human genital strains, one a human mouth strain (B3), one a rat strain (Kon), and one a saprophytic strain isolated 
from sewage (Laidlaw A). Cross-complementfixation tests were done with these antisera and various PPLO strains. The results of the experiments are shown in Tables I and II. Antigens made from Laidlaw A strain were too anticomplementary for use in complement fixation, an antigen made from a second saprophytic strain isolated from sewage, Laidlaw B, was not; it cross-reacted with Laidlaw A antiserum to high titre $(1,280)$ and thus provided a suitable substitute for Laidlaw $A$ in the tests.

Table I shows that crossing occurred between all strains and all antisera tested; the end titres given by a particular strain with the entire range of antisera provided a means of classifying the strain serologically. Strains of different origin behaved dissimilarly and strains of common origin behaved similarly. For instance, human genital strains could be distinguished serologically from all the human mouth strains and from all the non-human strains tested, whereas all six human mouth strains gave the same titre with mouth strain antiserum and with the other PPLO strains.

A total of 56 PPLO strains isolated from the human urogenital system were examined serologically; each strain was tested against three or more antisera to human genital PPLO and to one or more of the other antisera. The results are summarized in Table II, which shows the number of strains tested with each anti-serum, and the end titres which they gave, homologous-strain titres being given in heavy type. Most of the genital strains crossed to the full titre (or nearly so) with genital-strain anti-serum,

TABLE I

CROSS REACTIONS IN COMPLEMENT-FIXATION TESTS BETWEEN VARIOUS PPLO STRAINS AND THEIR ANTISERA

\begin{tabular}{|c|c|c|c|c|c|c|c|c|c|c|c|}
\hline & & \multicolumn{10}{|c|}{ Antiserum to PPLO Species } \\
\hline \multirow{2}{*}{\multicolumn{2}{|c|}{ Antigen }} & \multicolumn{6}{|c|}{ Human Genital } & \multirow{2}{*}{$\begin{array}{c}\text { Human } \\
\text { Mouth } \\
\text { (B3) }\end{array}$} & \multirow{2}{*}{$\underset{\text { (Kon) }}{\text { Rat }}$} & \multirow{2}{*}{$\begin{array}{c}\text { PP } \\
\text { Cattle } \\
\text { (C) }\end{array}$} & \multirow{2}{*}{$\begin{array}{l}\text { Saprophytic } \\
\text { (Laidlaw A) }\end{array}$} \\
\hline & & 56 & 58 & 75 & 95 & 160 & 184 & & & & \\
\hline$\underset{\text { Genital }}{\text { Human }}$ & $\begin{array}{r}56 \\
58 \\
75 \\
95 \\
160 \\
184\end{array}$ & $\begin{array}{l}5,120 \\
5,120 \\
5,120 \\
5,120 \\
1,280 \\
1,280\end{array}$ & $\begin{array}{r}20,480 \\
20,480 \\
640 \\
2,560 \\
5,120 \\
5,120\end{array}$ & $\begin{array}{l}2,560 \\
2,560 \\
2,560 \\
5,120 \\
2,560 \\
2,560\end{array}$ & $\begin{array}{r}5,120 \\
5,120 \\
2,560 \\
10,240 \\
2,560 \\
2,560\end{array}$ & $\begin{array}{r}640 \\
1,280 \\
1,280 \\
1,280 \\
1,280 \\
640\end{array}$ & $\begin{array}{l}640 \\
640 \\
320 \\
320 \\
640 \\
640\end{array}$ & $\begin{array}{r}640 \\
320 \\
320 \\
320 \\
1,280 \\
1,280\end{array}$ & $\begin{array}{l}320 \\
640 \\
640 \\
320 \\
640 \\
640\end{array}$ & $\begin{array}{l}80 \\
80 \\
80 \\
80 \\
80 \\
80\end{array}$ & $\begin{array}{l}80 \\
80 \\
80 \\
80 \\
80 \\
80\end{array}$ \\
\hline $\begin{array}{l}\text { Human } \\
\text { Mouth }\end{array}$ & $\begin{array}{l}\text { (B3) } \\
\text { Five Others }\end{array}$ & $\begin{array}{c}1,280 \\
640-1,280\end{array}$ & $\begin{array}{l}5,120 \\
5,120\end{array}$ & $\begin{array}{l}2,560 \\
2,560\end{array}$ & $\begin{array}{l}2,560 \\
2,560\end{array}$ & $\begin{array}{l}640 \\
640\end{array}$ & $\begin{array}{l}640 \\
640\end{array}$ & $\begin{array}{c}10,240 \\
5,120-10,240\end{array}$ & $\begin{array}{l}640 \\
640\end{array}$ & $\begin{array}{r}40 \\
40-80\end{array}$ & $\begin{array}{c}160 \\
160-320\end{array}$ \\
\hline Rat Strains & $\begin{array}{l}\text { (Kon) } \\
\text { (C) } \\
\text { (B) } \\
\text { (L) }\end{array}$ & $\begin{array}{l}320 \\
320 \\
320 \\
320\end{array}$ & $\begin{array}{l}80 \\
80\end{array}$ & $\begin{array}{l}160 \\
160\end{array}$ & $\begin{array}{l}320 \\
320\end{array}$ & $\begin{array}{l}160 \\
160\end{array}$ & $\begin{array}{l}160 \\
160\end{array}$ & $\begin{array}{l}160 \\
160\end{array}$ & $\begin{array}{r}10,240 \\
5,120 \\
1,280 \\
2,560\end{array}$ & $\begin{array}{r}160 \\
160 \\
80 \\
80\end{array}$ & $\begin{array}{l}80 \\
80 \\
80 \\
80\end{array}$ \\
\hline PP Cattle & $\begin{array}{c}\text { (C) } \\
\text { Two Others }\end{array}$ & $\begin{array}{l}80 \\
80\end{array}$ & $\begin{array}{l}80 \\
80\end{array}$ & $\begin{array}{l}80 \\
80\end{array}$ & $\begin{array}{l}80 \\
80\end{array}$ & $\begin{array}{l}80 \\
80\end{array}$ & $\begin{array}{l}80 \\
80\end{array}$ & $\begin{array}{l}160 \\
160\end{array}$ & $\begin{array}{l}320 \\
320\end{array}$ & $\begin{array}{l}1,280 \\
1,280\end{array}$ & $\begin{array}{l}20 \\
20\end{array}$ \\
\hline \multicolumn{2}{|c|}{ Saprophytic (Laidlaw B) } & 160 & 80 & 80 & 80 & 80 & 80 & 320 & 160 & 160 & 1,280 \\
\hline
\end{tabular}

TABLE II

TITRES GIVEN BY ANTIGENS PREPARED FROM STRAINS OF HUMAN GENITAL PPLO WITH ANTISERA TO VARIOUS TYPES OF PPLO

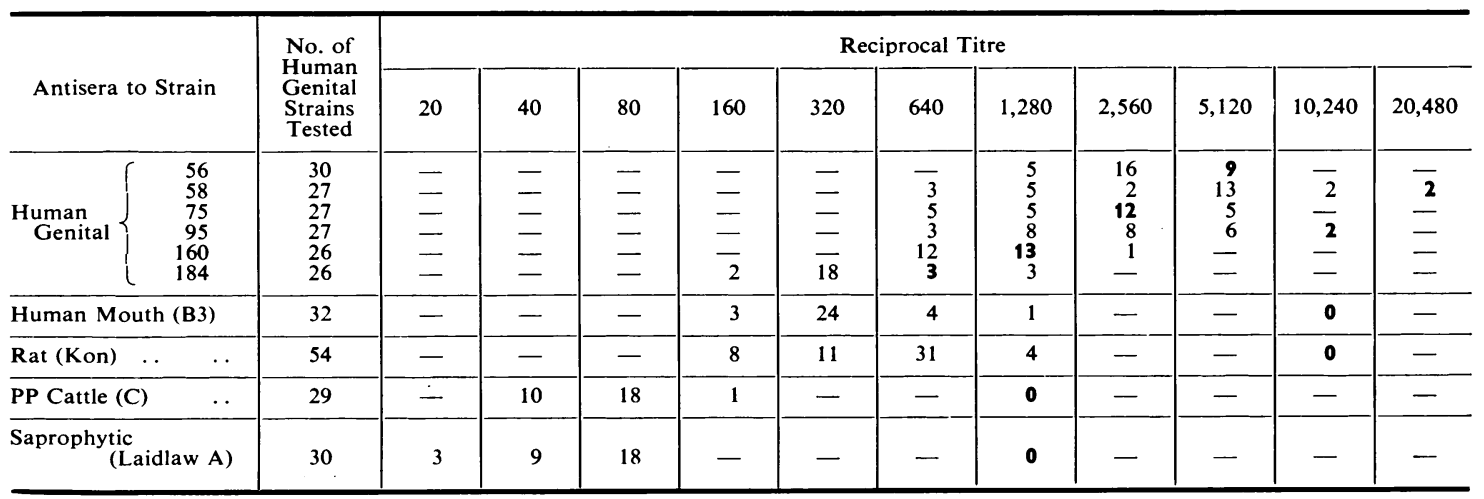


but they all gave titres with antisera to mouth and non-human strains that were considerably lower than the homologous titre. It is clear from these experiments that the human genital strains form a serological group distinct from that of the other PPLO strains, but they appear to be not quite antigenically homogeneous amongst themselves. The strain used for detecting antibodies in human sera (strain 56) crossed with thirty human genital strains to much the same titre as the homologous strain, which suggests that this strain contains an antigen common to the human genital strains of PPLO. If this is so, the routine antigen made from strain 56 would detect antibodies to all strains of human genital PPLO.

Examination of Human Sera.-The sera examined are classified in Table III according to type and sex of donor. The children's sera were from patients without genital symptoms at the Fountain Hospital, Tooting, or sera sent to the Great Ormond Street Hospital for toxoplasma tests or to the Colindale Public Health Laboratories for whooping cough trials.

Distribution of PPLO Antibodies.-A serum was taken to be positive if it reacted with either, or both, the $F$ and the $B$ antigen at an arbitrarily chosen titre of 10 . The proportion of positive sera varies from one group to another (Table I). The results were analysed by means of the $\chi^{2}$ test; significantly different incidences $(P \leqslant 0.05)$ of positive sera in the various groups are as follows:

(i) V.D. clinic patients higher than medical outpatients, blood donors, and children $(P<0 \cdot 01)$. (ii) Medical outpatients higher than blood donors and children $(P=0.02)$.

(iii) Women from the London Hospital V.D. Clinic higher than gynaecological patients from the same hospital $(P=0.01)$.

(iv) Gynaecological patients higher than antenatal patients $(P<0.02)$.

(v) V.D. clinic women higher than V.D. clinic men $(P<0.01)$.

There was no significant difference between V.D. clinic patients from the two hospitals $(P=0 \cdot 3)$ or between sexes in medical outpatients, blood donors, and children.

As regards the end titres of positive sera (Table IV, opposite), an analysis of variance indicates that the distribution of titres within the various groups does not differ significantly.

The proportion of sera in all groups reacting at a titre of 10 or more with one or both of the two antigens was as follows:

$$
\begin{array}{llll}
\text { F only } & \ldots & \ldots & 43 \text { per cent. } \\
\text { B only } & \ldots & . & 21 \text { per cent. } \\
\text { F + B } & \ldots & . & 36 \text { per cent. }
\end{array}
$$

In the $(F+B)$ group, the $F$ titre was higher in 14.4 per cent., the $B$ titre in 9.4 per cent., and the titres were equal in $12 \cdot 3$ per cent.

The serum titres against $F$ and $B$ were to some extent independent (Table V, opposite); that is to say that a high or low $F$ level might be accompanied by either a high or a low B level. In ten cases out of 205 the titre for one antigen preparation was more than eight times greater than the titre for the other. This suggests that in boiling the PPLO suspension another antigen has been unmasked, or that the

\begin{tabular}{|c|c|c|c|c|c|c|c|c|c|c|}
\hline & \multirow{3}{*}{ Group Examined } & \multicolumn{3}{|c|}{ Total } & \multicolumn{3}{|c|}{ Male } & \multicolumn{3}{|c|}{ Female } \\
\hline & & \multirow{2}{*}{$\begin{array}{c}\text { Number } \\
\text { Tested }\end{array}$} & \multicolumn{2}{|c|}{ Positive } & \multirow{2}{*}{$\begin{array}{c}\text { Number } \\
\text { Tested }\end{array}$} & \multicolumn{2}{|c|}{ Positive } & \multirow{2}{*}{$\begin{array}{c}\text { Number } \\
\text { Tested }\end{array}$} & \multicolumn{2}{|c|}{ Positive } \\
\hline & & & No. & $\begin{array}{c}\text { Per } \\
\text { cent. }\end{array}$ & & No. & $\begin{array}{c}\text { Per } \\
\text { cent. }\end{array}$ & & No. & $\begin{array}{l}\text { Per } \\
\text { cent. }\end{array}$ \\
\hline \multirow{3}{*}{$\begin{array}{l}\text { V.D. } \\
\text { Patients }\end{array}$} & St. Mary's Hospital, Paddington & 346 & 129 & $37 \cdot 3$ & 116 & 22 & $19 \cdot 0$ & 230 & 107 & $46 \cdot 5$ \\
\hline & $\begin{array}{ccc}\text { Whitechapel } & \text { Clinic, } & \text { London } \\
\text { Hospital } & \ldots & . .\end{array}$ & 354 & 109 & $31 \cdot 6$ & 168 & 31 & $18 \cdot 5$ & 186 & 78 & $41 \cdot 9$ \\
\hline & $\begin{array}{lllll}\text { Total } & \ldots & \ldots & \ldots & \ldots\end{array}$ & 700 & 238 & $34 \cdot 2$ & 284 & 53 & $18 \cdot 7$ & 416 & 185 & $44 \cdot 5$ \\
\hline \multirow{5}{*}{$\begin{array}{l}\text { Non-V.D. } \\
\text { Patients }\end{array}$} & $\begin{array}{c}\text { Medical Outpatients } \\
\text { Hospital) }\end{array}$ & 198 & 12 & $6 \cdot 1$ & 111 & 5 & $4 \cdot 5$ & 87 & 7 & $8 \cdot 1$ \\
\hline & $\begin{array}{l}\text { Ante-natal Patients (St. An- } \\
\text { drew's Hospital, Billericay). }\end{array}$ & - & - & - & - & - & - & 96 & 6 & $6 \cdot 3$ \\
\hline & $\begin{array}{cr}\text { Gynaecological } & \text { Patients (Lon- } \\
\text { don Hospital) } & \ldots\end{array}$ & - & 一 & - & - & - & - & 44 & 9 & $20 \cdot 4$ \\
\hline & $\begin{array}{l}\text { Blood Donors (N.W. London } \\
\text { Transfusion Centre) .. }\end{array}$ & 297 & 6 & $2 \cdot 1$ & 188 & 2 & $1 \cdot 1$ & 109 & 4 & $3 \cdot 7$ \\
\hline & Children under 13 years of age & 104 & 2 & 2 & 72 & 2 & $2 \cdot 8$ & 32 & 0 & - \\
\hline
\end{tabular}

TABLE III

DISTRIBUTION OF PPLO ANTIBODIES IN HUMAN SERA 
TABLE IV

END TITRES OF POSITIVE SERA

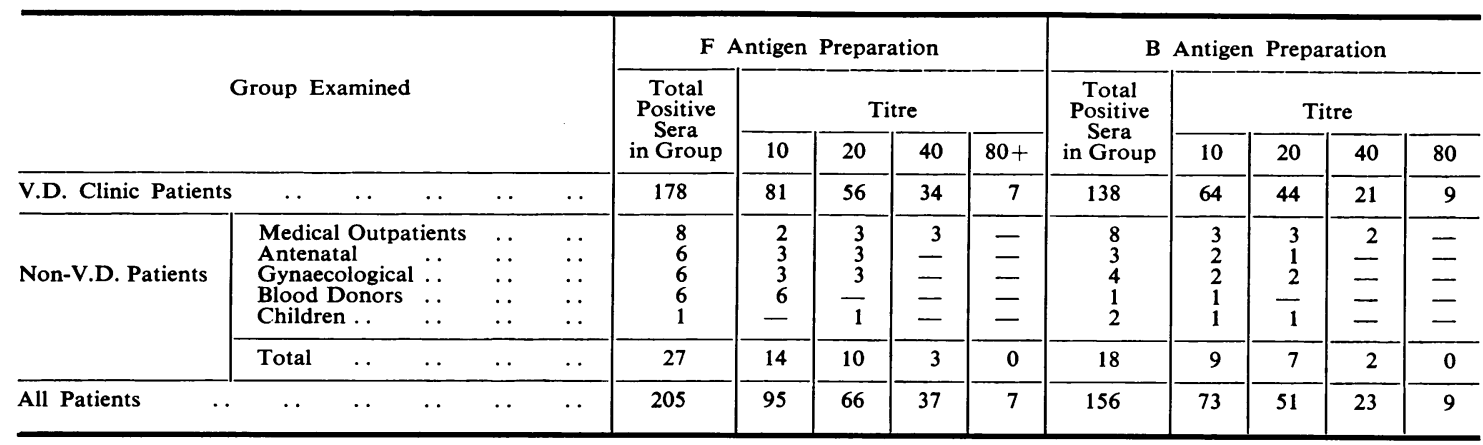

TABLE V

F AND B TITRES FOR POSITIVE HUMAN SERA REACTING WITH BOTH ANTIGENS

\begin{tabular}{|c|c|c|c|c|}
\hline \multirow{2}{*}{$\begin{array}{l}\text { Titre with } \\
\text { B Antigen }\end{array}$} & \multicolumn{4}{|c|}{ Titre with $F$ Antigen } \\
\hline & $<10$ & 10 & $20-40$ & $80-160$ \\
\hline$<10$ & - & 65 & 46 & 4 \\
\hline 10 & 33 & 18 & 22 & 2 \\
\hline $20-40$ & 30 & 12 & 30 & 2 \\
\hline $80-160$ & 4 & - & 3 & 2 \\
\hline
\end{tabular}

distribution of more than one antigen on the surface of the PPLO particle has been radically changed; but that all the antigens concerned stimulate antibody formation in varying degrees during infection.

\section{V.D. Clinic Patients}

PPLO Antibodies and V.D. History.-Case histories of 423 of the V.D. clinic patients were examined. These included the majority of the men and about half of the women patients at the V.D. clinics chosen at random for serological test; the proportion of sero-positive to sero-negative patients was the same as in the total group. Past and present venereal disease was recorded; though it was realized that the past V.D. history might not be complete or reliable. The patients were classified as in Table VI. The data were submitted to the $\chi^{2}$ test (significance level $P \leqslant 0.05$ ), on the assumption that the proportion of positive sera in the "total V.D. clinic patient" group (Table III) represented the expected proportion of positive sera in a group for which the V.D. history had no association with the serological result. The only groups in which the proportion of positive sera differed significantly from that in the "total V.D. clinic patient" group were:

(i) Males with a history of syphilis or yaws,

(ii) Both men and women with "no V.D. history".

The absence of any significant difference between the N.G.U. group and the V.D. clinic patients as a whole was of special interest because of the suspected relationship between N.G.U. and PPLO. To eliminate the possibility that patients in this group were being tested before detectable antibodies were present in the serum, the N.G.U. group was sub-divided (Table VI) into patients presenting with their first

TABLE VI

ANALYSIS OF CASE HISTORIES OF V.D. CLINIC PATIENTS

\begin{tabular}{|c|c|c|c|c|c|c|c|c|c|c|c|c|c|c|c|c|}
\hline \multirow{3}{*}{ Sex } & \multirow{3}{*}{$\begin{array}{c}\text { PPLO } \\
\text { Complement- } \\
\text { Fixation } \\
\text { Test }\end{array}$} & \multirow{3}{*}{$\begin{array}{l}\text { Per cent. in Total } \\
\text { Group with } \\
\text { Positive PPLO } \\
\text { Complement- } \\
\text { Fixation } \\
\text { Test } \\
\text { (from Table III) }\end{array}$} & \multicolumn{6}{|c|}{$\begin{array}{l}\text { Non-Gonococcal Urethritis, } \\
\text { Cervicitis, or Vaginitis }\end{array}$} & \multirow{2}{*}{\multicolumn{2}{|c|}{ Gonorrhoea }} & \multirow{2}{*}{\multicolumn{2}{|c|}{$\begin{array}{l}\text { Syphilis } \\
\text { or Yaws }\end{array}$}} & \multirow{2}{*}{\multicolumn{2}{|c|}{$\begin{array}{c}\text { Trichomonas } \\
\text { vaginalis }\end{array}$}} & \multirow{2}{*}{\multicolumn{2}{|c|}{$\begin{array}{l}\text { No V.D. } \\
\text { History }\end{array}$}} \\
\hline & & & \multicolumn{2}{|c|}{ Total } & \multicolumn{2}{|c|}{$\begin{array}{c}\text { First } \\
\text { Attack }\end{array}$} & \multicolumn{2}{|c|}{$\begin{array}{l}\text { Previous } \\
\text { Attacks }\end{array}$} & & & & & & & & \\
\hline & & & No. & $\begin{array}{l}\text { Per } \\
\text { cent. }\end{array}$ & No. & $\begin{array}{l}\text { Per } \\
\text { cent. }\end{array}$ & No. & $\begin{array}{c}\text { Per } \\
\text { cent. }\end{array}$ & No. & $\begin{array}{l}\text { Per } \\
\text { cent. }\end{array}$ & No. & $\begin{array}{l}\text { Per } \\
\text { cent. }\end{array}$ & No. & $\begin{array}{l}\text { Per } \\
\text { cent. }\end{array}$ & No. & $\begin{array}{l}\text { Per } \\
\text { cent. }\end{array}$ \\
\hline \multirow{2}{*}{ Male } & + & $18 \cdot 7$ & 12 & $\begin{array}{c}14 \cdot 8 \\
P=0 \cdot 5\end{array}$ & 6 & $14 \cdot 6$ & 6 & 15 & 18 & $P \stackrel{20}{=0} \cdot 3$ & 15 & $\begin{array}{c}62 \\
P<0.01\end{array}$ & - & - & 2 & $P<0^{4} \cdot 01$ \\
\hline & - & & 69 & & 35 & & 34 & & 71 & & 9 & & & & 50 & \\
\hline \multirow{2}{*}{$\begin{array}{c}\mathrm{Fe}- \\
\text { male }\end{array}$} & + & $44 \cdot 5$ & 35 & $P \stackrel{50}{=0 \cdot 3}$ & 24 & 47 & 11 & 58 & 25 & $P=0.38$ & 24 & $P \stackrel{46}{=0 \cdot 7}$ & 7 & $\begin{array}{c}47 \\
P=0.7\end{array}$ & 5 & $P<0.02$ \\
\hline & - & & 35 & & 27 & & 8 & & 41 & & 28 & & 6 & & 20 & \\
\hline
\end{tabular}


attack of the disease and those who had previously had one or more attacks. Table VI shows that these two subgroups displayed the same antibody distribution, as did the group of women with non-specific infection of the cervix and vagina reclassified on the same basis. Of fourteen women who were contacts of men with N.G.U., two were sero-positive.

In patients from V.D. clinics the proportion of positive sera was significantly higher than in other hospital patients (Table III). Table VI shows a similar trend amongst the V.D. clinic patients themselves; among those men and women who actually had V.D. the proportion of positive sera was significantly higher than among those who had no V.D. history but had attended the clinic because they were merely worried, or were suffering from penile abrasions, warts, etc.

For men with a history of syphilis or yaws the proportion of positive sera was significantly high. A cross-reaction between the PPLO antigen and Wassermann positive sera might account for this, particularly as three of the females with a positive PPLO test proved to be Wassermann-positive infants with congenital syphilis. But this interpretation is not consistent with the results of a series of serological tests for syphilis and yaws made at the time of the PPLO test in a number of the patients. Of 48 patients serologically positive for syphilis or yaws (SY +), only 27 (including two which proved to be falsely positive) were also positive in the PPLO complement-fixation tests with $F$ or $B$ antigen preparations. Moreover, in both positive and negative PPLO groups, there was a good proportion of strongly positive SY + sera. There was no association between SY + and reactivity with either the F or the $B$ antigen alone. Thus, if there is any antigenic relation between Wassermann antigens and the human PPLO, it is clearly minor, and cannot account for the association of the two kinds of positive serological reaction. In this connexion it is noteworthy that PPLO were isolated from the serous fluid of the syphilitic chancre in two of three men examined.

As regards the clinical interpretation of the titres, it is to be noted that the higher PPLO titres occurred in all groups of patients (Table VI), though the numbers in many groups were too small to be reliable as numerical evidence. Unfortunately it was not possible to examine antibody levels in subsequent specimens of serum, because the majority of patients defaulted in their attendance at the clinic; but in the few positive sera re-tested within a month there was no alteration in titre. One individual, who was free from clinical symptoms, and from whose urine PPLO were isolated on several occasions during
6 weeks, was never sero-positive, either with the routine antigen or with an antigen made from his own strain.

Reiter's Disease.-The sera from nineteen patients with Reiter's disease, and the synovial fluid from two, were examined for PPLO antibodies. All were negative except one which had a titre of 10 with both $F$ and $B$ antigens. Two of the sero-negative patients were re-tested after an attack of urethritis; in one the titre was 20 with the $F$ antigen, and the other remained negative.

Comparisons of Serological Results with Culture Results.-In 26 V.D. clinic patients, ten gynaecological patients, and five others, the serological tests were contemporaneous with cultural tests. (Klieneberger-Nobel, 1958). The results were as follows:

\begin{tabular}{ll|ll|c}
\hline \multicolumn{2}{c|}{ Culture } & \multicolumn{2}{c|}{ PPLO Antibodies } & \multicolumn{2}{c}{ No. of Cases } \\
\hline Positive & $\ldots$ & $\begin{array}{ccc}\text { Present } \\
\text { Absent }\end{array}$ & $\ldots$ & 9 \\
\hline Negative & $\ldots$ & $\begin{array}{cc}\text { Present } \\
\text { Absent }\end{array}$ & $\ldots$ & 11 \\
\hline
\end{tabular}

In five of these cases, the patient's serum was also tested with antigens made from his own strain of PPLO; the result was identical with that obtained with the routine antigen.

As a $\chi^{2}$ test showed, the distribution of cases in the four groups does not differ significantly from the distribution to be expected if there was no association whatever between the presence of PPLO in the genital tract and that of PPLO antibody in the blood. However, the group of 41 cases is heterogeneous, as regards patients, type of disease, and stage of disease at which the cultural and serological tests were made. The absence of association does not therefore contradict the strong association between cultural and serological positive results which is evident when the various groups are considered as populations rather than as individuals (see below). Melén and Gotthardson (1955) detected complement-fixing antibodies to PPLO in the absence of cultivable genital PPLO and found that the presence of PPLO in the genital tract was not necessarily followed by the formation of detectable antibodies.

\section{Discussion}

There is circumstantial evidence that human genital PPLO are transmitted by sexual intercourse (Dienes and Smith, 1942; Morton, Smith, and Leberman, 1951). If their presence in the urogenital tract leads to detectable antibodies, then in any group the 
incidence of antibodies should be related to the probability of infection.

The incidence of antibodies to human genital PPLO was roughly in accordance with the expected frequency of venereal disease in the various groups of subjects tested. In patients with venereal disease the proportion of positive sera was highest; in blood donors and children it was the lowest; and in unconfirmed venereal disease suspects, and gynaecological, medical, and antenatal outpatients the proportions were intermediate, diminishing in that order. It is to be expected that blood donors and children would be relatively free from venereal disease, owing to high standards of hygiene and small opportunity for infection. Amongst the intermediate groups the incidence would be expected to depend on the environment and mores of the population from which they were drawn. Thus Shepard (1954) suggested that different sexual behaviour might account for the different incidence of human genital PPLO found in Negro and white students. Infection, of course, is not wholly the outcome of sexual promiscuity, and it is possible that women suffering from apparently non-venereal gynaecological complaints are in fact infected with PPLO (Gotthardson and Melén, 1953).

The trend of the serological findings reported here agrees with the results of Klieneberger-Nobel (1959) for cultivation of PPLO from the urogenital tract. Thus she isolated PPLO from 56 per cent. of women and 26 per cent. of men attending V.D. clinics, and from about 20 per cent. of gynaecological and antenatal patients, but never from boys under the age of puberty and only rarely from healthy adults. This distribution is very similar to that found for PPLO antibodies. The only striking discrepancy in the two series of results was for antenatal patients; the cultural tests were made on patients attending the London Hospital and the serological tests on patients living in a country area, so that different opportunities for infection in the two groups might explain the discrepancy.

Since PPLO antibodies are found in PPLO infections in man (Stokes, 1955) and in rats infected with a PPLO causing polyarthritis in rats (Klieneberger-Nobel and Card, unpublished), it seems likely that the antibodies in human sera are the result of infection, at some time, with human genital PPLO. It is not possible to draw conclusions about the exact role of PPLO in non-gonococcal infections, since there was little opportunity to study antibody levels in patients with recently acquired infections. PPLO antibodies occurred in patients with a history of non-gonococcal genital infection, and in patients with other venereal diseases-a result which is not altogether unexpected in view of the frequency with which PPLO are isolated from the genital tract of patients with gonorrhoea and trichomonal infections (Klieneberger-Nobel, 1959) and even from syphilitic chancres. The relation of PPLO antibody to immunity and to the presence of detectable PPLO in the genital tract is unknown, and a more precise survey of the course of the disease in terms of both serology and culture is needed to establish the significance of a positive serum reaction in an individual patient.

The human genital PPLO strains fell into one serological group; Nicol and Edward (1953) found only one serologically distinctive strain in 91 strains examined. But Huijsmans-Evers and Ruys (1956) found three serological groups which could also be distinguished by cultivation and biochemical characteristics; the majority of their strains ("M. hominis") fell into the group with cultivation characteristics very similar to those examined here. These workers also found that human genital PPLO could be distinguished serologically from human mouth strains, but that there was considerable cross-reaction between mouth strains and the " $M$. hominis" group. Dienes and Madoff (1953) also reported that human mouth and genital strains were serologically distinct. The antigenic differences found between PPLO isolated from different animal species supports the findings of Klieneberger (1938) and Warren and Sabin (1942).

\section{Summary}

Serological examination of PPLO strains isolated from the human genital tract showed that they belonged to the same serological group; these strains could be distinguished serologically from PPLO isolated from the human mouth and from PPLO isolated from various animal species and from sewage. The singularity of the serological type of the genital strains made possible a survey of complement-fixing antibodies in terms of a single representative PPLO antigen.

Human sera were examined for complementfixing antibodies to human genital PPLO. Patients from venereal disease clinics had the highest incidence of antibodies (34 per cent.); blood donors and children had the lowest ( 2 per cent.); and medical, gynaecological, and antenatal out-patients gave intermediate values. Among the V.D. clinic patients, antibodies were more frequent in women (45 per cent.) than in men (18 per cent.). The distribution of antibodies was in accord with the frequency of venereal disease to be expected in the different groups of subjects investigated, and ran roughly parallel 
with the frequency with which PPLO could be isolated from the urogenital tract.

I am indebted to my colleagues Dr. G. Csonka of St. Mary's Hospital, and Drs. J. K. Oates and R. D. Catterall of the London Hospital for providing specimens and clinical information. I also wish to thank Dr. L. Potaschmacher, St. Andrew's Hospital, Billericay; Dr. J. C. W. MacFarlane, The Hospital for Sick Children, Great Ormond Street; Dr. G. Plaut, North London Blood Transfusion Centre, Edgware; Dr. Naomi Datta, Public Health Laboratories, Colindale; Dr. B. H. Kirman, Fountain Hospital, Tooting; and Dr. D. Erskine, Dreadnought Seamen's Hospital, Greenwich, for kindly providing sera and specimens.

Miss Margaret Beech performed some of the preliminary experiments.

\section{REFERENCES}

Beveridge, W. I. B., Campbell, A. D., and Lind, P. E. (1946). Med. J. Aust., 1, 179.
Campbell, A. D., and Turner, A. W. (1936). Bull. Coun. sci. industr. Res. Aust., No. 97, p 11.

Dienes, L., and Edsall, G. (1937). Proc. Soc. exp. Biol. (N. Y.), 36, 740.

and Madoff, S. (1953). Ibid., 82, 36.

Ed and Smith, W. E. (1942). Proc. Soc. exp. Biol. (N. Y.), 50, 99.

Edward, D. G. ff. (1954). J. gen. Microbiol., 10, 27.

Gotthardson, A., and Melén, B. (1953). Acta path. microbiol. scand. 33, 291.

Harkness, A. H. (1950). "Non-Gonococcal Urethritis". Livingstone, Edinburgh.

- and Henderson-Begg, A. (1948). Brit. J. vener. Dis., 24, 50.

Huijsmans-Evers, A. G. M., and Ruys, A. C. (1956). Antonie van Leewwenhoek, 22, 377

Klieneberger, E. (1938). J. Hyg. (Camb.), 38, 458.

Klieneberger-Nobel, E. (1959). Brit. med. J., 1, 19.

Mayer, M. M., Osler, A. G., Bier, O. G., and Heidelberger, M. (1946). J. exp. Med., 84, 535.

Melén, B., and Gotthardson, A. (1955). Acta path. microbiol. scand., 37, 196.

Morton, H. E., Smith, P. F., and Leberman, P. R. (1951). Amer. J. Syph., 35, 14

Nicol, C. S., and Edward, D. G. ff. (1953). Brit. J. vener. Dis., 29, 141.

Price, I. N., Orpwood, and Wilkinson, A. E. (1947). Brit. J. vener. Dis., 23, 124

Shepard, M. C. (1954). Amer. J. Syph., 38, 113.

Stokes, E. J. (1955). Lancet, 1, 276.

Warren, J., and Sabin, A. B. (1942). Proc. Soc. exp. Biol. (N.Y.), 51, 24.

Zavagli, V. (1951). Bull. Off. int. Epiz., 36, 336. 